JFTH, Vol. 13, Issue 2, (2016)

ISSN: 2314-7024

\title{
INVESTIGATING THE RELATIONSHIP BETWEEN HOTEL EMPLOYEES' Perception OF Organizational Politics (POP) AND Their APPLICATION OF IMPRESSION MANAGEMENT (IM) BEHAVIORS
}

\author{
Rania Hafez Gharib \\ Assistant Professor, Hotel Studies Department \\ Faculty of Tourism and Hotels, University of Sadat City
}

\begin{abstract}
The aim of this study is to examine the relationship between hotel employees' perception of organizational politics (POP) and their application of impression management (IM) behaviors. Data were collected by developed questionnaire. Originally 300 questionnaires were distributed among employees working in different departments of four and five star hotels in Alexandria. Only 210 questionnaires were returned giving a response rate of $70 \%$. It was found that there was not a significant relationship between employees' POP and their application of IM behaviors. Also, it was found that there were no significant differences between employees' gender and age concerning their POP. However, there have been significant differences between employees' POP in relation to their educational level, hierarchical level and work tenure. Furthermore, there have been significant differences between employees' application of IM behaviors regarding their age, gender, educational level, hierarchical level and work tenure.
\end{abstract}

Keywords: Organizational Politics (OP), Perception of Organizational Politics (POP), Impression Management (IM) Behaviors, Hotel employees

\section{Introduction}

Organizational politics have been the main subject for several studies in previous studies in the last four decades (Ofoegbu \&Ayobani, 2013; Yilmaz, 2014). Organizational politics (OP) are described as a group of behaviors to achieve personal interests at the expenses of others' interests (Poon, 2003; Rutherford et al., 2008). A workplace can be characterized as a social marketplace where employees try to benefit from it as much as they can, so they engage in political behavior to attain benefits (Poon, 2003). This occurred especially within organizations characterized by scarce resources, uncertainty and lack of trust (Parker et al., 1995).

Organizational politics (OP) should be understood based on how people see it rather than what it actually represents (Tang et al., 2015). So, perception of organizational politics (POP) can be used as a scale to measure organizational politics (Ferris et al., 1989). The importance of studying OP and POP comes from their negative effects on work either on the workers or the work environment outcomes as shown in many previous studies (Ferris et al., 1989; Ferris et al., 2000; Valle \& Perrewe, 2000; Bozeman et al., 2001). 
In the same context, impression management (IM) as a political behavior (Ferris et al., 2007; Ebrahimi et al., 2013) is how people behave in special way to position themselves in a desirable image in front of others (Gardner \& Martinko, 1988; Ariffin et al., 2013). Impression management (IM) behaviors are used by employees in work settings for many reasons as getting jobs, enhancing themselves during interviews, attaining career success and in determining employees performance appraisal ratings (Wayne \& Ferris, 1990; Ellis et al., 2002; Kristof-Brown et al,. 2002; Bolino et al., 2006).

Many studies investigated how individuals' perception of politics in their organizations can affect the usage of IM behavior (Ferris \& Kacmar, 1992; Ferris et al., 2000; Kacmar et al., 2004; Fang \& Chen, 2008; Yilmaz, 2014). The aim of this study is to investigate the relationship between perception of organizational politics (POP) and IM behaviors among hotel employees. Few studies have examined POP and IM behaviors in it (Tezer \& Daskin, 2012; Yilmaz, 2014). In addition, as hotels are considered labor intensive, they become appropriate work environment for practicing (OP) and IM behaviors.

\section{Review of literature}

\section{Organizational politics and perceptions of organizational politics}

Organizations contain various people of different interests, attitudes and values. This increases the chance among employees to be struggled about resources and promotion (Ebrahimi et al., 2013). Organizational politics (OP) was increasingly known in management literature especially in the last four decades (Ofoegbu \&Ayobani, 2013; Yilmaz, 2014). Organizational politics are a group of actions not officially used by an organization' s members to affect others to attain their own personal goals regardless to others interests (Vigoda, 2000; Kacmar et al., 2004; Fang\& Chen, 2008). Organizational politics (OP) are defined as "a social influence process through which behavior is laid out to achieve short-term or long term personal concerns either compatible with or at the expense of others' concerns" (Ferris et al., 1989, p 145 cited in Rutherford et al., 2008).

According to Parker et al. (1995) and Tariq et al. (2014) as there are scarce resources and competitive work environment, there is high politics. Individuals start to participate and use political behavior to achieve their own interests and to increase their opportunities to promotion. Tezer \& Daskin (2012) assured in their study that the limited organizational resources and the competitive working environment lead to following political behavior among their individuals more than those organizations without limited resources.

Likewise, there are many researchers which studied the perceptions of organizational politics (POP) (Vigoda, 2000; Rutherford et al., 2008; Ghafoor et al., 2009; Saleem et al., 2015). Perception means how individuals sense and mean their environment. Persons act depending on how they perceive reality not reality itself (Lewin, 1936 cited in Tang et al., 2015). Accordingly, op should be understood based on how people see it rather than what it actually represents (Tang et al., 2015). Ferris et al. (1989) proposed the concept of perception of organizational politics scale (POPs) to measure organizational politics. It describes how persons think their work environment as political and consequently unfair. POP leads to form employees' attitudes, when employees increasingly perceive their working environment as political, the level of justice, equity and fairness decrease (Kacmar and Ferris, 1991; Ferris \& Kacmar, 1992). 


\section{Predictors of organizational politics}

POPs are influenced by organizational environment and personal factors (Singh \& Tolani, 2012). Vigoda (2000) stated that the difference in education, tenure, hierarchical level and gender makes persons perceive politics in different ways. Vigoda and Cohen (2002) stated that lower level employees perceive their work environment as more political than higher level employees, which perceive their work as less of politics. Concerning tenure, as employees work for long time in the organization, they become seasoned to the negative organizational environment and politics and can operate in this environment. They perceive less of politics than those with lower tenure (Valle and Perrewe, 2000). This may be due to knowledge, experiences and skills obtained through their working years, employees with increased tenure perceive their working environment less uncertainty and less political (Goodman et al., 2011).

Regarding individual gender, it has been found that there is a difference between male and female employees in their perceptions and expectations toward their work. These expectations and perceptions may direct their behaviors and actions in their work (Mensah, 2014). Ferris et al. (1989) and Vigoda and Cohen (2002) found that women perceived more politics and were more impacted by organizational politics comparing to men. When women perceived high level of politics they feel more stress, less job satisfaction and organizational commitment than did male employees (Bodla et al., 2012). One other important predictor of POP is employees' level of education. Vigoda and Cohen (2002) stated that employees with high education level can fill high positions in the organization which make them perceive their work environment as less political than other employees with lower education. Age is another important predictor of POP. According to Ghafoor et al. (2009) there is a significant relationship between employees' age and their perception of organizational politics as the age of employees increase, their pop will increase.

$\mathbf{H}_{1:}$ There are differences between gender (1a), age (1b), educational level (1c), hierarchical level (1d) and work tenure (1e) of the employees and POP.

\section{POP and work outcomes}

It has been reported that there are great bad effects of OP and POP on work outcomes either on the workers or the work environment (Ferris et al., 1989; Ferris et al., 2000; Bozeman et al., 2001). Rutherford et al. (2008) and Tariq et al. (2014) found that POP increased job anxiety, decreased job satisfaction and increased work withdrawal. In the same context, Drory (1993), Valle \& Perrewe (2000) and Bozeman et al., (2001) showed in their studies that there is a negative relationship between POP and job satisfaction, organizational commitment and job involvement. Vigoda (2000) stated that there was a positive relationship between POP and employees' intention to quit and a negative relationship between POP and employees' performance. Additionally, Ugu \& Onyishi (2013) examined the relationship between POP and work engagement. They found that POP were negatively related to work engagement. In hospitality industry, some studies revealed that there was a positive relationship between POP and employees burnout (Karatepe et al., 2012; Dust \& Ebadzadeh, 2014) and between POP and turnover (Tezer \& Daskin, 2012).

\section{Dimensions of POPs}

Kacmar and Ferris (1991) mentioned that POP have three dimensions namely (a) general political behavior, (b) go along to get ahead and (c) pay and promotion policies. General political behavior involves all actions of employees directed to achieve their goals and get good outcomes. "Go along to get ahead" means that employees keep silent and do not take any actions toward any situation to make it in his best interest (Kacmar \& Ferris, 1991; Bryne, 2005). The pay and promotion dimension is the 
organization and employees' politically behavior regarding promotional policies and decision making (Adebusuyi et al., 2013).

\section{Impression Management (IM)}

Impression management (IM) means how people behave in special way to position themselves in a desirable image in front of others (Gardner \& Martinko, 1988; Ariffin et al., 2013). Goffman (1959) was the first one who introduced IM concept. He described IM as how a person can influence others to form his own personality. He also showed that people can use behaviors and tactics as a tool to manage other individuals (Ghara et al., 2013; Ebrahimi et al., 2013; Gwal, 2015). To apply IM successfully, individuals need to be more skilled in IM behaviors (Harris et al., 2007). IM is defined as the way and behaviors used by people through which they influence others to control their images in others' eyes to achieve their specific goals (Rosenfeld et al., 1995; Bolino \& Turnley, 1999; Bolino \& Turnley, 2001; Singh\& Vinnicombe, 2001; Ariffin et al., 2013). Many previous studies discussed IM concept especially in work settings. As employees face intense competition, they try to control their images in the eyes of their customers, colleagues, supervisors and subordinates in such a way to be looked valued to the organizations (Abdel Wahab et al., 2008). While individuals may use IM tactics in their daily life, others may apply them upon the situation. Also, personal characteristics could contribute to political behaviors and IM tactics (Ferris et al., 1989; Ghara et al., 2013).

Other studies revealed that people often use IM for many purposes as: getting jobs (Ellis et al., 2002), enhancing themselves during interviews (Kristof-Brown et al., 2002), be liked, looked potent and efficient (Ebrahimi et al., 2013), attaining career success (Wayne \& Ferris, 1990; Judge \& Bretz, 1994). Also, IM is considered an important element in determining employees' performance appraisal ratings and how supervisors like subordinates (Linden \& Wayne, 1995; Bolino et al., 2006). Tzeng et al., (2013) explained this issue due to that when supervisors evaluate their subordinates they affect by their social skills effectiveness more than objective job related criteria.

\section{Classifications of IM tactics}

There are several IM tactics and taxonomies. Tedeschi and Melburg (1984) classified IM tactics into assertive and defensive tactics. Assertive tactics are used when individuals want to develop a certain reputation in others' mind not only for a specific situation such as using ingratiation and supplication (Fang\& Cheng, 2008). On the other hand, defensive tactics are applied to enhance and repair an unpreferable image especially due to poor performance such as the use of execuses and appologies (Fang \& Cheng, 2008). Another classification of IM tactics is supervisor- focused, self-focused and job- focused (Wayne \& Ferris, 1990). Supervisor- focused tactics include ingratiatory behavior which is directed toward supervisor as favor rendering and opinion conformity. Self- focused tactics are how employees appear nice, polite and efficient in order to enhance their images and performance in their supervisors' view. As for job-focused tactics are those used by employees to seem more qualified at their jobs (Yilmaz, 2014).

Jones and Pittman (1982) divided IM tactics into five tactics namely; (a) self- promotion, (b) exemplification, (c) ingratiation, (d) intimidation and (e) supplication. Self- promotion means that employees magnify their achievements and abilities to be looked efficient and qualified (Gwal, 2015). Exemplification tactic is used by employees to show themselves as models. Ingratiation is when an employee does favors to others or adulates others to be seemed as likable person. Additionally, opinion conformity is a kind of ingratiation (Gwal, 2015). By using intimidation tactics, employees want to be looked dangerous and generally flow from high level to low level (Jones \& Pittman, 1982; 
Rosenfeld et al., 1995). The last IM tactics in Jones\& Pittman classification is supplication where individuals declared weakness in order to be seemed as needy (Rosenfeld et al., 1995).

The tactics of ingratiation, self-promotion and exemplification can produce positive outcomes for all involved (Harris et al., 2007). Gwal (2015) showed that ingratiation is the most applied tactic which can benefit the organization if it is used in moderate manner, however, if it is used too much could lead to dishonesty environment within the organization (Ghara et al., 2013).

\section{Perceptions of organizational politics and impression management}

Vigoda and Cohen (2002) showed that political behavior and POP should be related in the work context which means that one' $\mathrm{s}$ perception of organizational politics adhere to applying political behavior. Despite IM is considered as a kind of political behavior (Ferris et al., 2007; Ebrahimi et al., 2013) and the success of IM depends on the political climate of the organization (Guadango \& Cialdini, 2007), few studies were investigated how individuals' perception of politics in their organizations can affect their usage of IM behavior (Ferris \& Kacmar, 1992; Ferris et al., 2000; Kacmar et al., 2004; Fang \& Cheng, 2008; Yilmaz, 2014). Kacmar et al. (1999) found that when the work environments are characterized by limited resources, insecurity and untrust, there is a strong relationship between POP and IM (cited in Nayyar \& Raja, 2012). Ferris and Kacmar (1992) revealed in their study that managers in organization used IM techniques to manage their political behavior in front of their employees. Kacmar et al. (2004) explained that the relationship between pop and IM appears strongly when evaluating employees' performance. An employee use IM tactics when he perceive that his work environment is political in order to view himself as important and vital to others and achieve some self-serving goals as attaining better job assignments and promotion (Valle \& Perrewe, 2000; Kacmar et al., 2004).

Yilmaz (2014) stated that IM behavior is more than a political tactic and perceptions of politics should be preceding of IM behavior that means when employees perceive their work environment as political, they apply IM behaviors and tactics. However, Fang and Cheng (2008) suggested that employees when they perceive their work environment as low political, they tend to use IM tactics. On the contrary, employees are less involved in IM behavior when they perceive their work environment as highly political since they believe that IM tactics would be useless and they avoid IM techniques. In the same context, Kacmar et al. (2004) mentioned that employees engage in IM behavior in order to get a competitive career advantage.

On the other hand, they do not believe that using IM behavior will be useful when they perceive their work environment as political as they think that their performance rating will remain constant whatever they do. In addition, some studies have been showed that IM moderates the relationship between politics and several work outcomes as job satisfaction, supervisors' rating of job performance (Valle \& Perrewe, 2000; Kacmar et al., 2004 Fang\& Cheng, 2008).

Accordingly, the following hypothesis is formulated:

H2: There is a significant relationship between employees' POP and their application of IM tactics

\section{Methods}

The sample included 5 hotels from five star hotels and 4 hotels from four star hotels in Alexandria. Originally, 300 questionnaires were distributed. Only 230 were returned and 210 were valid giving a response rate of $70 \%$. A questionnaire was developed to explore the perceptions of hotel employees in four and five star hotels in Alexandria toward organizational politics (POP) in their hotels and their application of impression management (IM) behaviors. The questionnaire was divided into three 
sections. The first section covered the demographic data and some related work data. The second one was designed to investigate employees' perceptions of organizational politics (POP). Questions in this section consisted of 15 statements based on Kacmar and Ferris (1991) and Kacmar and Carlson (1997) POP scale. A five point scale has been used ranging from strongly disagree to strongly agree. The last section measured employees' IM behaviors. It included 22 statements divided into five subsections namely; self-promotion, ingratiation, exemplification, intimidation and supplication based on Bolino and Turnely (1999) scale which based on Jones and Pittman IM scale. A five point scale has been used ranging from never behave to often behave. Statistical Package for Social Sciences (SPSS) was used for statistical analysis.

\section{Results \& Discussion}

\section{Reliability and validity analysis}

Cronbach's coefficient alpha was used to measure the internal consistency of the questionnaire. It ensures that the specified items are sufficient in their representation of the underlying constructs. In addition to obtain the content validity, existing scales were identified from the literature and conducting interviews with some practitioners from the hotel industry, asking them to give their comments on the instrument. Cronbach's alpha should meet the recommended significance of 0.60 or higher. All constructs of the survey had $70.8 \%$ of reliability coefficient. (Table1).

Table (1) Reliability Coefficient of the questionnaire

\begin{tabular}{|c|c|c|c|}
\hline \multicolumn{2}{|l|}{ Constructs } & No. of items & Cronbach's Alpha \\
\hline $\begin{array}{l}\text { Independent } \\
\text { variables }\end{array}$ & POP & 15 & 0.658 \\
\hline \multirow{5}{*}{$\begin{array}{c}\text { Dependent variable } \\
\text { ( IM ) }\end{array}$} & Self-promotion & 4 & 0.916 \\
\hline & Ingratiation & 4 & 0.917 \\
\hline & Exemplification & 4 & 0.774 \\
\hline & Intimidation & 5 & 0.879 \\
\hline & Supplication & 5 & 0.940 \\
\hline \multicolumn{2}{|l|}{ Overall survey scale } & 37 & 0.708 \\
\hline
\end{tabular}

\section{Respondents' Profile}

The demographic profiles of the hotel respondents are shown in Table (2). In terms of gender, more than the half of respondents $(57.1 \%)$ were male, and (42.9\%) were female. In terms of age, $(87.6 \%)$ of respondents were 40 years or less, and only (12.4\%) were more than 40 years of age. According to educational background of the hotel respondents, $(41.5 \%)$ of respondents graduated from technical schools, and (45.7\%) of the samples had bachelor degree. On the other hand, $20(9.5 \%)$ respondents claimed that they held post graduate degree, and only 7 respondents mentioned that had secondary and preparatory degrees.

Table (2) The demographic profile of respondents

\begin{tabular}{|c|c|c|}
\hline Gender & Frequency & Percentage \\
\hline Male & 120 & $57.1 \%$ \\
\hline Female & 90 & $42.9 \%$ \\
\hline Total & $\mathbf{2 1 0}$ & $\mathbf{1 0 0 \%}$ \\
\hline Age & Frequency & Percentage \\
\hline
\end{tabular}




\begin{tabular}{|c|c|c|}
\hline Less than 30 & 93 & $44.3 \%$ \\
\hline From 30 to 40 & 91 & $43.3 \%$ \\
\hline More than 40 & 26 & $12.4 \%$ \\
\hline Total & $\mathbf{2 1 0}$ & $\mathbf{1 0 0 \%}$ \\
\hline Educational Level & Frequency & Percentage \\
\hline Technical School & 87 & $41.4 \%$ \\
\hline Bachelor degree & 96 & $45.7 \%$ \\
\hline Post graduate degree & 20 & $9.5 \%$ \\
\hline Other & 7 & $3.3 \%$ \\
\hline Total & $\mathbf{2 1 0}$ & $\mathbf{1 0 0 \%}$ \\
\hline
\end{tabular}

\section{Respondents Work-Related Information}

Some work-related information of the hotel respondents are demonstrated in Table (3) which revealed that $50.5 \%$ of the respondents worked in the back of the house and $49.5 \%$ worked in the front of the house area. The majority of the respondents belonged to the middle level of management $(97,46.2 \%)$ followed by the top level of management $(57,27.1 \%)$ and the bottom level management came at the last $(56,26,7 \%)$. Concerning the working years of the employees in the current hotel, $104(49.5 \%)$ of them stated they work from 5 to 10 years and 79 (37.6\%) worked for less than 5 years. Only $(12.9 \%)$ worked more than 10 years in the current hotel. Regarding the employees span of control, 65 (30.9\%) of employees mentioned that they do not have any employees reported to them, 66 (31.4\%) indicated that from 5 to 10 employees reported to them, $(24.8 \%)$ of the respondents mentioned that less 5 employees reported to them, whereas only (12.9\%) had more than 10 employees reported to them.

Investigating the responses about the employees working departments, $(81,38.6 \%)$ of the respondents worked in food and beverage department, $(54,25.7 \%)$ worked in front office department, $(19.5 \%)$ worked in housekeeping department and $8.1 \%$ worked in accounting. Also, there were $8.1 \%$ worked in other departments as engineering, human resources and purchasing departments.

Table (3) Respondents work-related information

\begin{tabular}{|c|c|c|}
\hline Type of department & Frequency & Percentage \\
\hline Front of the house & 104 & $49.5 \%$ \\
\hline Back of the house & 106 & $50.5 \%$ \\
\hline Total & $\mathbf{2 1 0}$ & $\mathbf{1 0 0 \%}$ \\
\hline Hierarchical level & Frequency & Percentage \\
\hline Top level management & 57 & $27.1 \%$ \\
\hline Middle level management & 97 & $46.2 \%$ \\
\hline Bottom level management & 56 & $26.7 \%$ \\
\hline Total & $\mathbf{2 1 0}$ & $\mathbf{1 0 0 \%}$ \\
\hline Work tenure & Frequency & Percentage \\
\hline Less than 5 years & 79 & $37.6 \%$ \\
\hline From 5 to 10 years & 104 & $49.5 \%$ \\
\hline More than 10 years & 27 & $\mathbf{1 0 0 \%}$ \\
\hline Total & $\mathbf{2 1 0}$ & Percentage \\
\hline $\begin{array}{c}\text { Number of employees who } \\
\text { report to you }\end{array}$ & Frequency & $30.9 \%$ \\
\hline None & 65 & \\
\hline
\end{tabular}




\begin{tabular}{|c|c|c|}
\hline Less than 5 employees & 52 & $24.8 \%$ \\
\hline From 5 to 10 employees & 66 & $31.4 \%$ \\
\hline More than 10 employees & 27 & $12.9 \%$ \\
\hline Total & $\mathbf{2 1 0}$ & $\mathbf{1 0 0 \%}$ \\
\hline The department you work in & Frequency & Percentage \\
\hline Food \& beverage & 81 & $38.6 \%$ \\
\hline Front office & 54 & $25.7 \%$ \\
\hline Housekeeping & 41 & $19.5 \%$ \\
\hline Accounting & 17 & $8.1 \%$ \\
\hline Other & 17 & $8.1 \%$ \\
\hline Total & $\mathbf{2 1 0}$ & $\mathbf{1 0 0 \%}$ \\
\hline
\end{tabular}

\section{Differences between employees' demographic variables and their POP}

Mann-Whitney test and Kurskal-Wallis test were used to investigate the differences between respondents' demographic variables as gender, age, educational level, hierarchical level and work tenure and their POP. Data shown in Table (4) demonstrated that there is no significant differences $(\mathrm{P}=0.403)$ between male and female regarding their perception of organizational politics. This means that (H1a) was not supported. Several studies supported that there is significant difference between male and female concerning their POP. It was found that women perceived their work environment as more political and were influenced by politics more than men who considered them as normal practices they adapted with and not impacted by them (Ferris et al. 1989; Drory \& Beaty, 1991; Vigoda and Cohen, 2002). However, Stewart et al. (2007) and Atinc et al. (2010) revealed in their study that there was no significant difference between male and female regarding their POP. They showed that there was no difference between them about their view to work environment.

In addition, Table (4) showed that there is no significant differences between employees' age relating to their perception of organizational politics $(\mathrm{P}=0.39)$. These results demonstrated that $(\mathrm{H} 1 \mathrm{~b})$ was not accepted. Ghafoor et al. (2009) mentioned that there is significant relationship between individuals' age and their perception of organizational politics. They found that as employees age increase, their POP will increase. On the contrary, Atinc et al. (2010) revealed that there wasn't significant difference between employees' age and their perception of organizational politics.

Table (4) Differences between employees pop concerning their gender and age

\begin{tabular}{|c|c|c|c|}
\hline Gender & $\mathbf{N}$ & Mean Rank & Sig. (P. value) \\
\cline { 1 - 3 } Male & 120 & 102.47 & \multirow{2}{*}{0.403} \\
\hline Female & 90 & 109.54 & \\
\hline Total & $\mathbf{2 1 0}$ & & \\
\hline Age & $\mathbf{N}$ & Mean Rank & Sig. (P. value) \\
\hline Less than 30 years & 93 & 117.39 & \multirow{2}{*}{0.39} \\
\hline From 30 to 40 years & 91 & 96.78 & \\
\hline More than 40 years & 26 & 93.48 & \\
\hline Total & $\mathbf{2 1 0}$ & & \\
\hline
\end{tabular}


Table (5) indicated the differences between employees' POP in relation to educational level, hierarchical level and work tenure. In terms of employees' educational level, results have showed that there are significant differences between their educational level and their pop. Therefore (H1c) was accepted. It was found that employees with lower educational level perceive their hotels as more highly political than those with higher educational level. As employees' educational level increases, they can fill higher positions in their hotels which make them feel trust and more certainty which influenced their perception about their hotels and perceive them as lower political (Cohen, 2003). On the other hand, employees with lower level of education they feel untrust and uncertainty about their jobs that affected their perception about their work environment as highly political (Vigoda and Cohen, 2002).

The tabulated data showed that there are significant differences between the hierarchical levels of employees concerning their pop. From these results (H1d) can be supported. Lower level employees perceive their work environment as more political than higher level employees, which perceive their work as less of politics (Vigoda and Cohen, 2002).

The results have been showed that there are significant differences between employees work tenure and their pop which supported (H1e). Employees who have worked for less than 5 years perceive their work climate as more highly political than those who worked from 5 to 10 years and who worked more than 10 years. When employees work for a long time in the organization, they become familiar with all policies and negative work environment which result in perceiving less politics than those who work for a short time. This may be due to their knowledge and experiences obtained through their working years which leads to perceive their working environment as less politics (Valle and Perrewe, 2000; Goodman et al., 2011). Also, when employees work for a long time in the organization, they establish social bonds with their colleagues which may influence their view about their organization and perceive as less political (Slaughter et al., 2007).

Table (5) Differences between employees' POP in relation to educational level, hierarchical level and work tenure

\begin{tabular}{|l|c|c|c|}
\hline \multicolumn{1}{|c|}{ Educational Level } & N & Mean Rank & Sig. (P. value) \\
\hline Technical School & 87 & 117.14 & \\
\cline { 1 - 3 } Bachelor Degree & 96 & 115.39 & \multirow{2}{*}{0.000} \\
\cline { 1 - 3 } $\begin{array}{l}\text { Post Graduate } \\
\text { degree }\end{array}$ & 20 & 90.50 & \\
\hline Other Total & 7 & 130.43 & \\
\hline \multicolumn{1}{|c|}{ Hierarchical Level } & 210 & 88.91 & \\
\hline $\begin{array}{l}\text { Top level } \\
\text { management }\end{array}$ & 57 & 96.48 & \multirow{2}{*}{0.000} \\
\hline $\begin{array}{l}\text { Middle level } \\
\text { management } \\
\text { (supervisors) }\end{array}$ & 97 & & \\
\hline
\end{tabular}




\begin{tabular}{|c|c|c|c|}
\hline $\begin{array}{l}\text { Bottom-line } \\
\text { management } \\
\text { (workers) }\end{array}$ & 56 & 138.01 & \\
\hline \multicolumn{1}{|c|}{ Total } & $\mathbf{2 1 0}$ & & \\
\hline Work tenure & & & \\
\hline Less than 5 years & 79 & 122.91 & \multirow{2}{*}{0.005} \\
\hline From 5 to 10 years & 104 & 100.28 & \multirow{2}{*}{} \\
\hline More than 10 years & 27 & 93.63 & \\
\hline Total & $\mathbf{2 1 0}$ & & \\
\hline
\end{tabular}

Differences between employees' demographic variables and their application of IM behavior Mann-Whitney test and Kurskal-Wallis test were used to investigate the differences between respondents' demographic variables as gender, age, educational level, hierarchical level and work tenure and their application of IM behavior.

Table (6) indicated the differences between employees' gender and age and their application of IM behavior in their hotels. Results showed there were significant between male and female and their application of IM tactics $(\mathrm{P}=0.031)$. This means that men and women differ in their application of IM behavior in their work. It was found that men are more applied IM tactics than women do. Singh and Vinnicombe (2001) and Singh et al. (2002) revealed in their studies that there were differences between men and women in using IM tactics. Men were using IM tactics more than women because they view them as natural and can get several benefits when they apply them. However, women did not want to use them at all in spite of their importance. Guadango and Cialdini (2007) mentioned that men used tactics that are compatible with their masculine gender role such as intimidation and selfpromotion. On the other hand, women used IM tactics which are in agreement with their feminine gender role as supplication. Also, results in table (6) revealed that there were significant differences between employees' age and their application of IM behavior $(\mathrm{P}=0.000)$. As employees' age increase, they tend to use IM tactics more than young employees.

Table (6) Differences between employees' application of IM behavior concerning gender and age

\begin{tabular}{|c|c|c|c|}
\hline Gender & N & Mean Rank & \multirow{2}{*}{ Sig. } \\
\hline Male & 120 & 112.83 & \multirow{2}{*}{0.031} \\
\hline Female & 90 & 94.65 & \\
\hline Total & 210 & & \multirow{2}{*}{ Sig. } \\
\hline Age & $\mathbf{N}$ & Mean Rank & \multirow{2}{*}{0.000} \\
\hline Less than 30 years & 93 & 81.94 & \\
\hline From 30 to 40 years & 91 & 122.45 & \\
\hline More than 40 years & 26 & 125.52 & \\
\hline Total & 210 & & \\
\hline
\end{tabular}

Table (7) demonstrated the differences between employees' educational level, hierarchical level and their work tenure regarding their application of IM behavior. Results showed that there were significant differences between employees' educational level and their application of IM tactics ( $\mathrm{P}=$ 
0.024). It was found that as employees' educational level increases, they extensively apply IM tactics. In terms of employees' hierarchical level, data showed that there were significant differences between employees' hierarchical level and their application of IM tactics $(\mathrm{P}=0.000)$. This means that as employees belonged to different hierarchical levels, they differ in their application of IM tactics. Also, it was revealed that as employees belonged to higher management levels, they apply IM tactics more than those belonged to lower management levels.

Data shown in table (7) demonstrated that there were significant differences between employees work tenure and their application of IM behavior $(\mathrm{P}=0.000)$. Results were shown that employees who work for more than 10 years apply IM behavior more than those who work from 5 to 10 years and who work for less than 5 years.

Table (7) Differences between employees' application of IM behavior in relation to educational level, hierarchical level and work tenure

\begin{tabular}{|c|c|c|c|}
\hline Educational Level & $\mathbf{N}$ & Mean Rank & Sig. \\
\hline Technical School & 87 & 105.63 & \multirow{4}{*}{0.024} \\
\hline Bachelor Degree & 96 & 114.07 & \\
\hline Post Graduate degree & 20 & 140.80 & \\
\hline Other & 7 & 95.23 & \\
\hline Total & 210 & & \\
\hline Hierarchical Level & $\mathbf{N}$ & Mean Rank & Sig. \\
\hline Top level management & 57 & 129.69 & \multirow{3}{*}{0.000} \\
\hline $\begin{array}{l}\text { Middle level } \\
\text { management } \\
\text { (supervisors) }\end{array}$ & 97 & 108.99 & \\
\hline $\begin{array}{c}\text { Bottom-line } \\
\text { management (workers) }\end{array}$ & 56 & 72.36 & \\
\hline Total & 210 & & \\
\hline Work tenure & $\mathbf{N}$ & Mean Rank & Sig. \\
\hline Less than 5 years & 79 & 70.08 & \multirow{3}{*}{0.000} \\
\hline From 5 to 10 years & 104 & 121.07 & \\
\hline More than 10 years & 27 & 143.98 & \\
\hline Total & 210 & & \\
\hline
\end{tabular}

\section{Relationship between POP and impression management dimensions}

It is observed from the following Table (8) that there is no significant relationship between employees perception of organizational politics and their IM tactics $(r=0.57)$. Also, it is shown that there is a statistically significant and positive relationship between POP and supplication variable $(r=-.136$, $\mathrm{p}<0.05$ ). On the other hand, POP shares high statistically significant and negative relationship with self-promotion $(\mathrm{r}=-.206, \mathrm{p}<0.01)$, Exemplification $(\mathrm{r}=-.170, \mathrm{p}<0.05)$, and Intimidation $(\mathrm{r}=-.213$, $\mathrm{p}<0.01)$. From the previous results, $\mathrm{H} 2$ was not supported. This means that when employees perceive their hotels as political they do not need to apply IM tactics. In spite of many studies showed that POP and IM behavior are related and when employees perceive their work environment as political, they begin to use IM behavior to obtain some advantages as attaining better job assignments, promotion and in evaluating employees' performance (Ferris and Kacmar, 1992; Valle and Perrewe, 2000; Ferris et al., 2000; Vigoda and Cohen, 2002; Ferris et al., 2007; Yilmaz, 2014). 
On the other hand, other previous studies proved that when employees perceive their work environment as highly political, they think that it is useless to use IM tactics as they think that whatever they do, they cannot gain any advantages as their performance rating will remain constant (Kacmar et al., 2004; Fang and Cheng, 2008).

Table (8) Correlation matrix of the study variable

\begin{tabular}{|c|c|c|c|c|c|c|c|}
\hline 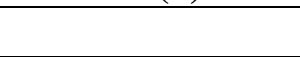 & 1 & 2 & 3 & 4 & 5 & 6 & 7 \\
\hline POP & 1 & & & & & & \\
\hline IM & $\begin{array}{l}.132- \\
.057 \\
210\end{array}$ & 1 & & & & & \\
\hline Self-promotion & $\begin{array}{l}-.206- \\
* * \\
.003 \\
210\end{array}$ & $\begin{array}{l}.601 * * \\
.000 \\
210\end{array}$ & 1 & & & & \\
\hline Ingratiation & $\begin{array}{l}.078 \\
.260 \\
210 \\
\end{array}$ & $\begin{array}{l}.215^{* *} \\
.002 \\
210 \\
\end{array}$ & $\begin{array}{l}.100 \\
.152 \\
210 \\
\end{array}$ & 1 & & & \\
\hline Exemplification & $\begin{array}{l}-.170- \\
* \\
.013 \\
210\end{array}$ & $\begin{array}{l}.751 * * \\
.000 \\
210\end{array}$ & $\begin{array}{l}.298 * * \\
.000 \\
210\end{array}$ & $\begin{array}{l}.160 * \\
.021 \\
210\end{array}$ & 1 & & \\
\hline Intimidation & $\begin{array}{l}-.213- \\
* * \\
.002 \\
210 \\
\end{array}$ & $\begin{array}{l}.729 * * \\
.000 \\
210\end{array}$ & $\begin{array}{l}.515 * * \\
.000 \\
210\end{array}$ & $\begin{array}{l}-.146- \\
* \\
.034 \\
210 \\
\end{array}$ & $\begin{array}{l}.569 * * \\
.000 \\
210\end{array}$ & 1 & \\
\hline Supplication & $\begin{array}{l}.136^{*} \\
.048 \\
210\end{array}$ & $\begin{array}{l}.390 * * \\
.000 \\
210\end{array}$ & \begin{tabular}{|l}
$-.252-$ \\
$* *$ \\
.000 \\
210 \\
\end{tabular} & $\begin{array}{l}-.099- \\
.151 \\
210\end{array}$ & $\begin{array}{l}.327 * * \\
.000 \\
210\end{array}$ & $\begin{array}{l}-.032- \\
.649 \\
210\end{array}$ & 1 \\
\hline
\end{tabular}

\section{Conclusion}

Organizations contain various people who have different interests, attitudes and values. This increases the chance between the employees to be struggled about resources and promotion. As there is scarce resources and competitive work environment as in the case of the hospitality industry, where there is high politics. Employees begin to engage in political behavior such as impression management behaviors to attain several benefits. The objective of this study was to investigate the relationship between hotel employees perception of organizational politics and their application of IM behaviors. The study showed that there was not significant relationship between employees' perception of organizational politics and their application of IM behaviors.

Examining the differences between some of the employees' demographic variables regarding their POP, it was found that there were not significant differences between employees' POP in relation to their gender and age. On the other hand, there have been significant differences between employees' 
POP in relation to their educational level, hierarchical level and work tenure. The study has shown that there were significant differences between employees' gender, age, educational level, hierarchical level and work tenure and their application of IM behaviors.

Finally, further researches are needed to examine the relationship between pop and IM behaviors in the hospitality industry and the relationship between them and the work outcomes as few studies were found in this field.

\section{References}

- Abdel Wahab, A. M.; Awad, A. M.; Elsayed, M. M., Elziady, A. R.,Ibrahim, S.M.; \& Khattab, A. S. (2008) 'Impression Management Behaviors and Leader-Member Exchange as Main Determinants of Employee Performance Ratings and Turnover Intentions - An Application on the Banking Sector', Master Thesis, Faculty of Commerce, Ain Shams University

- Adebusuyi, A.; Olasupo, A. \& Idehen, E. (2013) 'Analysis of the perception of organizational politics by employees of Obafemi Awolowo University", Bangaladesh E- Journal of Sociology, 10 (1), 51-58

- Ariffin, T. M; Mustaffa, B. C. \& Salleh, A. N. (2013) 'Proposing instrument to measure impression management among flood victims', International Journal of Science and Humanity, 3 (6), 538-542

- Atinc, G.; Darrat, M.; Fuller, B. \& Parker, B. (2010) 'Perceptions of organizational politics: A meta-analysis of theoretical antecedents', Journal of Managerial Issues, 22 (4), 494-513

- Bodla, A. M; Danish, Q. R. \& Nawaz, M. M. (2012) 'Mediating role of perceived organizational politics relating job characteristics to morale', African Journal of Business Management, 6 (15), 5185-5192

- Bolino, M. \& Turnely, W. (1999) 'Measuring impression management in organizations: A scale development based on the Jones and Pittman taxonomy', Organizational Research Methods, 2 (2), 187-206

- Bolino, M. \& Turnely, W. (2001) 'Achieving desired images while avoiding undesired images: Exploring the role of self-monitoring in impression management', Journal of Applied Psychology, 86 (2), 351-360

- Bolino, M.; Varela, A. J.; Bande, B. \& Turnely, W. (2006) 'The impact of impression management tactics on supervisor ratings of organizational citizenship behavior', Journal of Organizational Behavior, 27, 281-297

- Bozeman, D. P; Perrewe, P. L; Hochwarter, W. A. \& Brymer, R. A. (2001) 'Organizational politics, perceived control and work outcomes: Boundary conditions on the effects of politics', Journal of Applied Social Psychology, 31(3), 486-503

- Bryne, Z. S. (2005) 'Fairness reduces the negative effects of organizational politics on turnover intentions, citizenship behavior and job performance', Journal of Business and Psychology, 20, 175-200

- Cohen, A. (2003). Multiple Commitments in the Workplace: An Integrative Approach.Mahwah,

- NJ: Lawrence Erlbaum Associates cited in Mensah, T. G. (2014) 'The relationship between perceived organizational politics, organizational commitment and organizational citizenship behavior among some selected public sector organizations in ACCRA', Master thesis, University of Ghana

- Dust, H. \& Ebadzadeh, K. (2014) 'Sensitivity and organizational politics as antecedents of burnout among frontline hotel worker', International Journal of Research in Social Sciences, 3 (5), 14-28

- Drory, A. (1993) 'Perceived political climate and job attitudes', Organization Studies, 14 (1), 59-71

- Drory, A. \& Beaty, D. (2001) 'Gender differences in the perception of organizational politics', Journal of Organizational Behavior, 12, 249-258

- Ebrahimi, E.; Tahmasebi, R.; Behrooz, A. \& Zadeh, E. (2013) 'Investigating the role of personality dimensions on impression management tactics', New York Science Journal, 6 (6), 35-43

- Ellis, A.; West, B.; Ryan, A. \& DeShon, R. (2002) 'The use of impression management tactics in structural interviews: A function of question type?', Journal of Applied Psychology, 1200-1208

- Fang, W. \& Chen, Y. (2008) ' The moderating effect of impression management on the organizational politicsperformance relationship', Journal of Business Ethics, 79, 263-277

- Ferris, R. G. \& Kacmar, M. (1992) 'Perceptions of organizational politics', Journal of Management, 18 (1), 93 116

- Ferris, G.R; Russ, G.S, \& Fandt, PM. (1989) 'Politics in organizations' In: Giacalone RA, Rosenfeld P, editors. Impression management in the organization, Hillsdale, NJ: Lawrence Erlbaum, pp. 143- 70

- Ferris, R. G.; Harrell-Cook, G. \& Dulebohn, H. J. (2000) 'Organizational politics: The nature of the relationship between politics perceptions and political behavior, Research in the Sociology of Organizations, 17, 89-130 
- Ferris, R. G.; Treadway, C. D.; Perrewe, L. P.; Brower, L. R.; Douglas, C. \& Lux, S. (2007) 'Political skill in organizations', Journal of Management, 33 (3), 290-320

- Gardner, W. \& Martinko, M. (1988) 'Impression management in organizations', Journal of Management, 14 (2), 321-338

- Ghafoor, M.; Danish, R. \& Malik, M. (2009) 'Relationship between age, perceptions of organizational politics and job satisfaction', Journal of Behavioral Sciences, 19 (12), 23-40

- Ghara, M.; Abdi, M.; Langari, A. F. \& Danaee, H. (2013) 'Evaluating the impression of positive and negative affectivity on the implementation of impression management tactics, Management Science Letters, 3, 1445-1458

- Goffman, E. (1959) 'The presentation of self in everyday life', Garden city, Bantam Books, New York cited in Ghara, M.; Abdi, M.; Langari, A. F. \& Danaee, H. (2013) 'Evaluating the impression of positive and negative affectivity on the implementation of impression management tactics, Management Science Letters, 3, 1445-1458

- Goodman, J. M.; Evans, W. R. \&Carson, C. M. (2011) 'Organizational politics and stress; perceived accountability as a coping mechanism', The Journal of Business Inquiry, 10, 66-80

- Guadango, E. R. \& Cialdini, B. R. (2007) 'Gender differences in impression management in organizations: A qualitative review', Springer Science, 1-13

- Gwal, R. (2015) 'Tactics of impression management: Relative success on workplace relationship', The International Journal of Indian Psychology, 2 (2), 37-44

- Harris, K.; Kacmar, H. \& Zivnuska, S. \& Shaw, J. (2007) 'The impact of political skill on impression management effectiveness', Journal of Applied Psychology, 92 (1), 278-285

- Jones, E. E., \& Pittman, T. S. (1982). Toward a general theory of strategic self presentation, Psychological perspectives on the Self, ed J.Suls, 1: 231-262.Hillsdale, NJ: Erlbaum cited in Gwal, R. (2015) 'Tactics of impression management: Relative success on workplace relationship', The International Journal of Indian Psychology, 2 (2), 37-44

- Judge, T. A. \& Bretz, R. D. (1994) 'Political influence behavior and career success', Journal of Management, 20, 43-65

- Kacmar, K. \& Ferris, G. (1991) 'Perceptions of organizational politics scale (POPs): Development and construct validation', Educational and Psychological Measurement, 51, 193-205

- Kacmar, K.M. \& Carlson, D.S. (1997) 'Further validation of the perceptions of politics scale (POPS): A multiple sample investigation', Journal of Management, 23 (5), 627-658

- Kacmar, K.M., Bozeman, D.P., Carlson, D.S. \& Anthony, W.P. (1999) 'An examination of the perceptions of organizational politics model: replication and extension', Human Relations, 52, 383-416 cited in Nayyar, S. \& Raja, N. (2012) 'The impact of impression management behavior on organizational politics among male and female employees in organic and mechanistic organizational systems of Pakistan telecommunication sector', Interdisciplinary Journal of Contemporary Research in Business, 3 (9), 914-924

- Kacmar, K.; Zivnuska, S.; Witt, L.; Carlson, D. \&Bratton, U. (2004) 'Interactive effects of impression management and organizational politics on job performance', Journal of Organizational Behavior, 25 (5), $627-$ 640

- Karatepe, O.; Babakus, E. \& Yavas, U. (2012) 'Affectivity and organizational politics as antecedents of burnout among frontline hotel employees', International Journal of Hospitality Management, 31, 66-75

- Lewin, K. (1936) 'Principles of topological psychology', Mc Graw- Hill, New York cited in Tang, Y.; Xue, X. \& Song, H. (2015) 'The relationship between political skill and employee voice behavior: From an impression management perspective', The Journal of Applied Business Research, 31 (5), 1877-1888

- Liden, C. R. \& Wayne, J. S. (1995) 'Effects of impression management on performance ratings: A longitudinal study', The Academy of Management Journal, 38 (1), 232-260

- Mensah, T. G. (2014) 'The relationship between perceived organizational politics, organizational commitment and organizational citizenship behavior among some selected public sector organizations in ACCRA', Master thesis, University of Ghana

- Nayyar, S. \& Raja, N. (2012) 'The impact of impression management behavior on organizational politics among male and female employees in organic and mechanistic organizational systems of Pakistan telecommunication sector', Interdisciplinary Journal of Contemporary Research in Business, 3 (9), 914-924

- Ofoegbu, O.E. \& Ayobami, P. A. (2013) 'Influence of perception of organizational politics on job satisfaction among university in Oyo town, Nigeria', European Journal of Business and Management, 5 (2), 162-168

- Parker, C.; Dipboye, L. R. \& Jackson, L. S. (1995) 'Perceptions of organizational politics: An investigation of antecedents and consequences', Journal of Management, 21 (5), 891-912 
- Poon, J. (2003) 'Situational antecedents and outcomes of organizational politics perceptions', Journal of Managerial Psychology' 18 (2), 138-155

- Rosenfeld, P.; Giacalone, R. \& Riordan, C. (1995) 'Impression management in organizations: Theory, measurement and practice, Routledge, New York

- Rutherford, M.; Miller, B. \& Kolodinsky, R. (2008) 'Perceptions of organizational politics: A meta-analysis of outcomes', Journal of Business Psychology, 22, 209-222

- Saleem, S.; Ahmad, R.; Ud Din, N.; Qadeer, F.; Shafique, M. \& Abbas, H. (2015) 'Impact of perceptions of organizational politics on employees' job outcomes: The moderating role of self-efficacy and personal political skills', Sei International (Lahore), 27 (3), 2729-2734

- Singh, S. \& Tolani, H. (2012) 'Perception of organizational politics and ingratiatory tactics: Mediating role of individual values', OJAS, 1, 1-11

- Signh, V. \& Vinnicombe, S. (2001) 'Impression management commitment and gender: Managing others' good opinions', Europe Management Journal, 19 (2), 183-194

- Singh, V.; Kumra, S. \& Vinnicombe, S. (2002) 'Gender and impression management: playing the promotion game', Journal of Business Ethics, 37, 77-89

- Slaughter, S. A., Ang, S., \& Boh, W. F. (2007) 'Firm-specific Human Capital and Compensation Organizational Tenure profiles: An archival analysis of salary data for IT professionals', Human Resource Management,46, 373-394

- $\quad$ Stewart, S.M.; Bing, M.N.; Gurys, M.L. \& Helford, M. (2007) 'Men, women\& perception of work environment, organizational commitment and turnover intentions', Business and Public Affair, 1(1), 56-72

- Tariq, I. M; Danish, R.; Humayon, A.; Aslam, N. \& Usman, A. (2014) 'Employee' s perceptions of organizational politics and stress at workplace: A comparative study of public and private sector universities', Research Journal of Recent Sciences, 3 (7), 44-52

- Tang, Y.; Xue, X. \& Song, H. (2015) 'The relationship between political skill and employee voice behavior: From an impression management perspective', The Journal of Applied Business Research, 31 (5), 1877-1888

- Tedeschi, J. \& Melburg, V. (1984) 'Impression management and influence in the organization', Research in the Sociology of Organization, Greenwich, CT: JAI Press, 3, 31-58

- Tezer, M. \& Daskin, M. (2012) 'Organizational politics and turnover: An empirical research from hospitality industry', Tourism, 6 (3), 273-291

- Tzeng, G. H.; Chiu, W. L. \& Chen, J. W. (2013) 'Do impression management tactics and/or supervisorsubordinate guanxi matter?', Knowledge-Based Systems, 40, 123-133

- Ugu, F. \& Onyishi, E. (2013). Exploring the Relationship between perceived Organizational

- Politics and Work Engagement: An Investigation in the Nigerian University Context.

- Presentations in the International Technology Education and Development Conference

- Preoceedings, 3568-3575 cited in Mensah, T. G. (2014) 'The relationship between perceived organizational politics, organizational commitment and organizational citizenship behavior among some selected public sector organizations in ACCRA', Master thesis, University of Ghana

- Valle, M. \& Perrewe, P. (2000) 'Do politics perceptions relate to political behaviors? Tests of an implicit assumption and expanded model', Human Relations, 53, 359-386

- Vigoda, E. (2000) 'Organizational politics, job attitudes and work outcomes: Exploration and implications for the public sector', Journal of Vocational Behavior, 57, 326-347

- Vigoda, E. \& Cohen, A. (2002) 'Influence tactics and perceptions of organizational politics: A longitudinal study', Journal of Business Research, 55, 311-324

- Wayne, S. J. \& Ferris, G. R. (1990) 'Influence tactics, affect and exchange quality in supervisor-subordinate interactions: A laboratory experiment and field study', Journal of Applied Psychology, 75, 487-499

- Yilmaz, O. D. (2014) 'Perception of organizational politics and impression management behaviors: A tourism industry perspective', International Journal of Business and Social Science, 5 (8), 98-109 